\title{
Customer integration strategies for innovation projects: anticipation and brokering
}

\author{
Patricia Sandmeier \\ ABB Switzerland Ltd., \\ Brown Boveri Strasse 6, \\ CH-5401 Baden, Switzerland \\ E-mail: patricia.sandmeier@ch.abb.com
}

\begin{abstract}
Integrating customer contributions into new product development provides an effective approach for successful product innovation, but little academic research explicitly addresses appropriate customer integration strategies. To explore such strategies, this study investigates the impact of different customer contribution types and timing. An analysis of four case studies with industrial goods developers in Northern Europe is used to draw a framework revealing two customer integration strategies: anticipation and brokering. As a practical implication, the careful selection of the customer integration strategy according to the company's industry establishedness and targeted degree of product newness is recommended.
\end{abstract}

Keywords: product innovation; customer integration; customer integration strategy; NPD; new product development; innovation process; anticipation, innovation brokering; degree of newness; industry establishedness.

Reference to this paper should be made as follows: Sandmeier, P. (xxxx) 'Customer integration strategies for innovation projects: anticipation and brokering', Int. J. Technology Management, Vol. x, No. x, pp.xxx-xxx.

Biographical notes: Patricia Sandmeier works for ABB Ltd. as Business Development Manager Sales Switzerland. She earned a PhD at the Department of Technology Management, University of St. Gallen (Switzerland) and was a visiting researcher at the University of New South Wales, Sydney (Australia) and at the University of California, Berkeley (USA). In her work, she explores novel concepts for early customer integration in innovation projects, such as Extreme Programming from software engineering. Her research interests include new product development issues, customer integration strategy and the management of open innovation projects.

\section{Introduction}

Managing product innovations involves a severe challenge to industrial firms, especially because the basic assumption that companies can anticipate demand and mobilise their scarce development resources as they have in the past no longer holds true in many cases. In fast moving industries for example, nearly two-thirds of product innovations fail after their launch, largely because companies must address rapidly evolving customer demands (Lempres, 2003). Industrial new product developers thus recognise the need to inject more customer know-how into their product innovation processes, and in many 
leading-edge companies, R\&D managers encourage direct interaction between the development team and customers, in contrast with traditional practices in which the marketing department would undertake customer research and throw the results 'over the wall' to R\&D (Holman et al., 2003).

However, confusion remains regarding the different possible strategies for integrating customers into $\mathrm{R} \& \mathrm{D}$ and their impact and value for product innovations. An ongoing debate considers whether customers inhibit or stimulate product ideas with high degrees of newness or if customer input leads only to incremental product innovations. Whereas von Hippel (1986, 1988; see also Lilien et al., 2002) proposes that users represent an important source of new product ideas, others suggest that listening to customers may limit the company to incremental product improvements (Ciccantelli and Magidson, 1993; Christensen, 1997; Kohn and Niethammer, 2002) that prove detrimental to innovation and firm performance (Macdonald, 1995; Callahan and Lasry, 2004).

The field of New Product Development (NPD) recognises that developing new products with high degrees of newness differs markedly from incremental NPD (O’Connor, 1998; Callahan and Lasry, 2004), but such a differentiation leaves blank spots in customer integration literature. Thus, this paper attempts to understand customer integration strategies and their causes and effects in terms of the degree of newness of the products developed.

To explore these aspects, we conducted a multiple case study in the field of industrial NPD in Northern Europe. Asking for the impact of customer integration characteristics on the degree of newness of new products we revealed two largely differing customer integration strategies: We found that innovation projects where companies hold a product leadership position tend to follow a strategy in which they anticipate their customers' needs. By contrast, those firms that cannot claim leadership status find more informal ways to integrate customers and apply more flexible product innovation processes through idea brokering. While anticipation tends to result in product innovations with a rather low degree of newness, the latter inventive and entrepreneurial brokering practices tend to produce new product solutions with a higher degree of newness than those resulting from anticipation strategies.

Thus, this paper contributes to innovation research by extending customer integration to a strategic terrain. In this context, it provides new perspectives about how firms might choose customer integration strategies appropriately to respond to new product requirements in terms of the degree of product newness. The results offer new insights regarding how to integrate customers into innovation projects effectively.

The remainder of this paper is organised as follows. First, we discuss relevant literature in the field of customer integration into product innovation processes. Second, we introduce two research questions that guide the investigation. Third, after describing the applied research approach, we present the findings of the case studies: the impact of the company's position in terms of industry establishedness and the characteristics pertaining to the anticipation and brokering strategies. Fourth, we discuss the implications of our findings for innovation research and corporate practice.

\section{Contrasts in customer integration literature}

Empirical research into customer integration shows that involving customer know-how in the development of product innovations prompts a higher degree of product newness, 
reduces innovation risks, and leads to more precise resource spending (Kohli and Jaworski, 1990; Bacon et al., 1994; Atuahene-Gima, 1995; Griffin and Hauser, 1996; Brockhoff, 2003). Most work in this field focuses on approaches in which customer integration provides a better understanding of customers' product requirements, which authors discuss as market orientation (Kohli and Jaworski, 1990; Atuahene-Gima, 1996), the voice of the customer (Griffin and Hauser, 1993), the virtual customer (Paustian, 2001; Dahan and Hauser, 2002), customer-driven innovation (Billington, 1998), or consumers as co-developers (Jeppesen and Molin, 2003).

The value of considering so-called lead users - who recognise their product needs in advance of other customers and significantly benefit from a new product solution - in the early stages of the innovation process is presented by von Hippel $(1976,1978,1988)$ and various other researchers. Specifically, the value of a product innovation increases when users bring their specialised need and preference know-how into the product innovation process. In turn, the resultant new products provide true value for customers and users (Herstatt and von Hippel, 1992; Lilien et al., 2002; Morrison et al., 2004; Lüthje et al., 2005). Ultimately, know-how provided by customers can result in the transmutation or evolution of the entire NPD challenge, because such knowledge redefines the problem and reorients approaches to address it (Clark and Fujimoto, 1990). Therefore, the integration of customers into the innovation process can elevate the understanding of a design challenge to a level that results in a solution that better serves the needs of the intended product users (Veryzer and Borja de Mozota, 2005).

However, existing research also notes the risks and downsides of customer integration. Various authors indicate that a company that does not select the right customers or fails to find appropriate ways to integrate them will not develop effective product innovations because they are too attentive to the needs of current customers (Macdonald, 1995; Callahan and Lasry, 2004). Brockhoff (2003) posits that selecting customers who actually contribute to NPD is, in practice, very challenging, because companies have no guarantee of finding the right partner, and the negative consequences of a poor collaboration can be significant. In addition, some authors find that customer integration into NPD leads only to incremental improvements of existing solutions instead of radically new products (Macdonald, 1995; Kohn and Niethammer, 2002). Hamel and Prahalad (1994) actually state that customers are notoriously lacking in foresight, and Martin (1995) suggests that firms should ignore their customers for NPD. These findings fall in line with Kohli and Jaworski's (1990) claims that a strong market orientation can inhibit organisations from developing truly breakthrough innovations.

Existing literature thus highlights that if a company does not succeed in finding the right course of action, customer integration can harm rather than contribute to product innovation efforts. But even though "finding of the right course of action" is acknowledged to be crucial, strategies for customer integration in innovation projects have been not explicitly addressed by research to date.

\section{Research questions}

Investigating different customer integration strategies should yield insights into the right way to work with customers. In the following, we develop two research questions pertaining to two main characteristics in which different strategies will vary: the type of the customer contribution and the timing of major customer participation during the 
product innovation process. These characteristics are put in perspective to the degree of the newness of the developed product (see Figure 1). This degree of newness serves as an effective measure because it influences the decision making associated with an innovation strategy from a practical standpoint (Hargadon, 2005).

Figure 1 Diagram of research questions

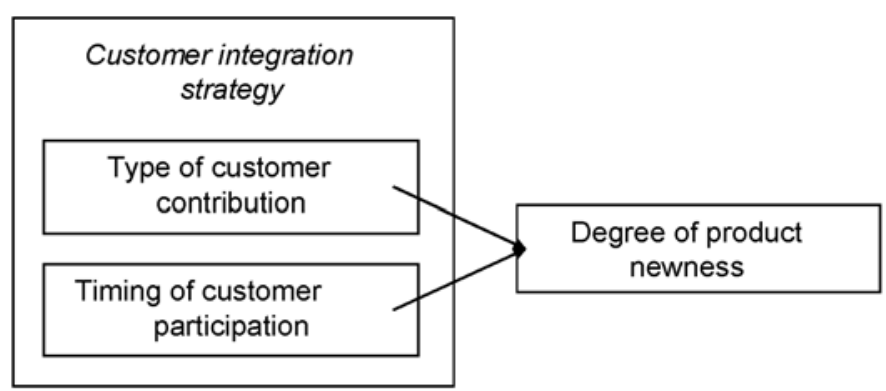

\subsection{Degree of newness}

The degree of newness of an innovative product represents an important variable, but its measurement is particularly difficult (Hauschildt and Schlaak, 2001; Brockhoff, 2003). A product innovation with a high degree of newness refers to a 'really new product' that "relies on technology never used in a specific industry before; has an impact on or causes significant changes in the whole industry; or is the first of its kind and entirely new to the market" (Song and Montoya-Weiss, 1998, p.126). Such product innovations also have been referred to as disruptive (Christensen, 1997) or radical (Rice et al., 2001; McDermott and O'Connor, 2002) innovations. In contrast, innovations of products with relatively low degrees of newness improve existing product solutions without introducing a completely new approach; thus, they have been referred to as incremental innovations (De Propis, 2002).

\subsection{Type of customer contribution}

The value of customer contributions to NPD projects depends on the choice of an appropriate contributing partner (Gruner and Homburg, 2000). Extending von Hippel's (1986, 1988) findings about lead user characteristics, Gruner and Homburg (2000) show that customers' representativeness of target markets and reputations in those markets provide discriminating criteria that can lead to stronger or weaker products. Similarly, Brockhoff (2003) suggests that it is not just customer creativity but also customers' demand potential that counts for NPD. Furthermore, other authors indicate the relevance of the customer organisation, its financial attractiveness, technological expertise, and past experience with co-development (Ganesan, 1994, Doney and Cannon, 1997). Additional relevant characteristics include objectivity, willingness to cooperate, market position, ability to maintain confidential information, and competitor ties (Shaw, 1985; von Hippel, 1986; Urban and von Hippel, 1988; Biemans, 1992; Herstatt and von Hippel, 1992; Ganesan, 1994; Bruce et al., 1995; Gruner and Homburg, 2000). Scott et al. (2003) further note that customers should have something specific to offer, such as significant revenue potential or other interesting products, that can be integrated 
for product innovation. Finally, still other authors find that unhappy customers can make valuable contributions to NPD (Morrison et al., 2004). On the basis of this work, several researchers have identified different roles that customers play during the product innovation process and note that their offers vary according to their role (see Table 1).

Table 1 Customer roles and offers in product innovation projects

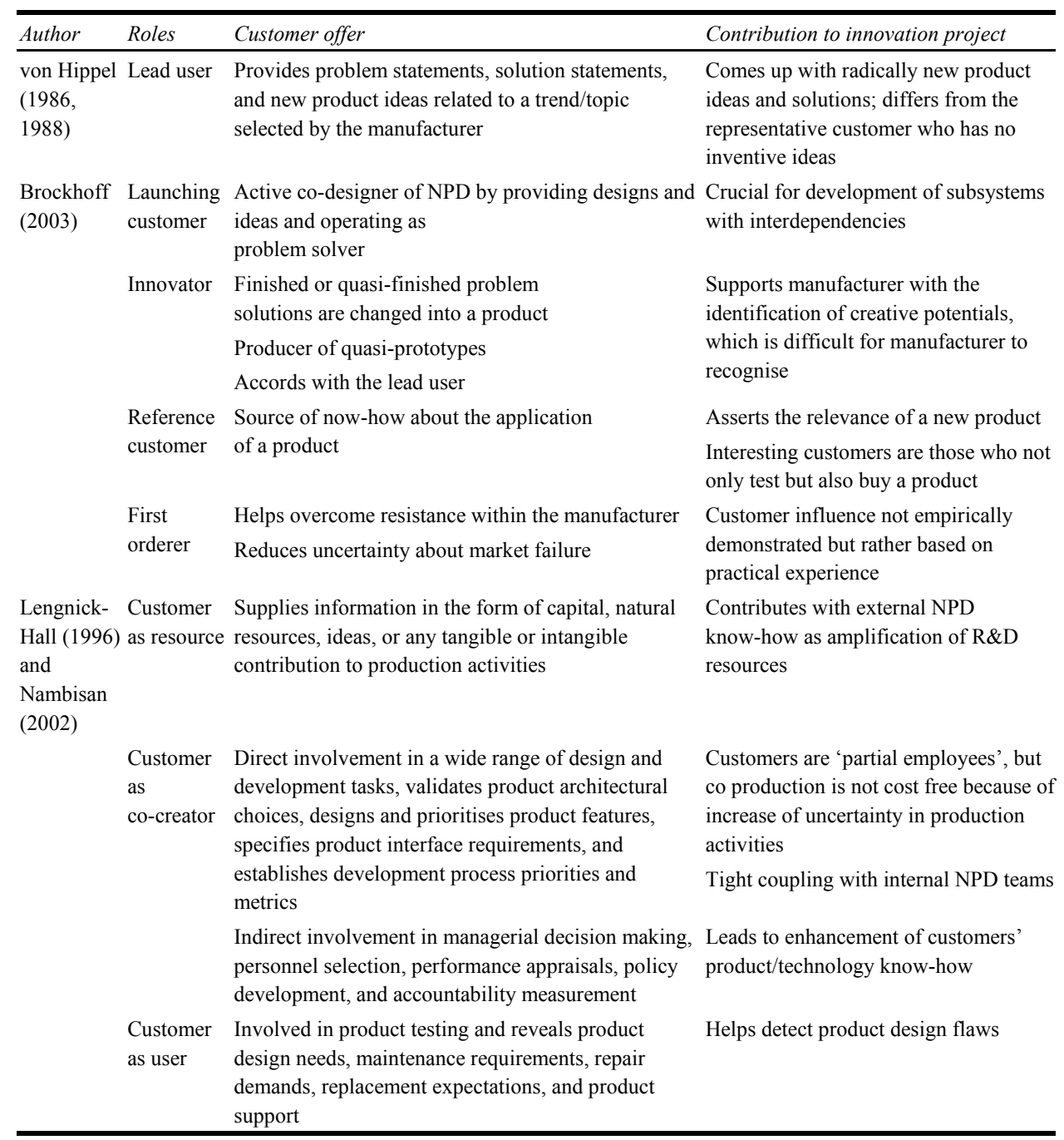

As Table 1 highlights, different customer roles and offers make differential contributions to innovation projects. Whereas an integration of lead users (von Hippel, 1986, 1988), launching customers, and innovators (Brockhoff, 2003), as well as customers as co-creators (Lengnick-Hall, 1996; Nambisan, 2002) tends to contribute in such a way that the new product solutions have a high degree of newness, an integration of reference customers, first orderers (Brockhoff, 2003) and customers as users (Lengnick-Hall, 1996; Nambisan, 2002) tends to ensure the applicability of a new product. 
However, the relationship between customer roles and their offers and the resulting degree of product newness does not appear explicitly in previous research, so this study first explores the impact of different types of customer contributions on the degree of newness of product innovations, in which different customer integration strategies differ.

Question 1: What is the impact of different types of customer contributions on the degree of product newness?

\subsection{Timing of customer participation}

Depending on the contribution required for a product innovation project, the extent and intensity of customer integration typically varies according to the stage of the product innovation process (Biemans, 1992; Gruner and Homburg, 2000). Companies must integrate the appropriate customer at the right time, with the proper involvement intensity, and with the most appropriate form of governance (von Hippel, 1977, 1986; Wynstra and Pierick, 2000; Lynch and O'Toole, 2003).

Overall, the most effective customer integration occurs when the development team has the flexibility to respond. Therefore, the best impact of customer integration - in terms of project costs, as illustrated by Figure 2 - is attained during the early phases of the product innovation process, the so-called innovation front-end or product definition phase (Kim and Wilemon, 2002).

Figure 2 Impact of customer integration on project costs

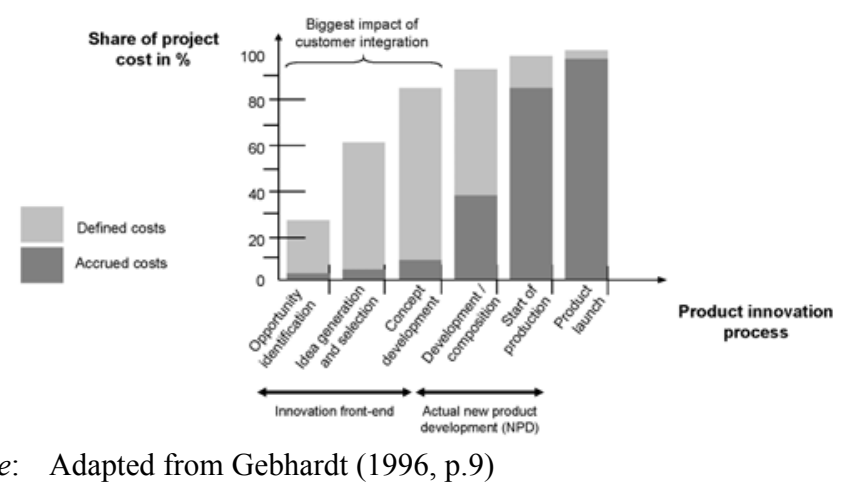

The innovation front-end determines up to $85 \%$ of total development costs (Buergel and Zeller, 1997; Herstatt and Verworn, 2002). It comprises several activities: identifying new opportunities for future products, generating and selecting new product ideas, and developing new product concepts. However, even though this phase typically is the least expensive portion of the overall innovation project in terms of accrued costs, most product developers spend little time in this stage for fear of duplicating marketing or $\mathrm{R} \& \mathrm{D}$ efforts or because they lack the know-how to manage this early innovation phase (Kline, 1985; Koen et al., 2001). Instead, product-developing companies concentrate on the actual NPD phase, during which the impact of customer integration is limited, because commonly used, predefined, and cost-driven NPD processes generally do not offer the required flexibility to respond to customer input acquired during these development phases (MacCormack et al., 2001). 
Given that the degree of product newness is expected to be influenced by the timing of the major customer participation in the innovation process, this aspect is addressed by the second research question:

Question 2: What is the impact of the timing of customer participation on the degree of product newness?

\section{Research methodology}

To explore the relationships among customer contributions, timing of customer integration, and product newness and thus obtain new insights about customer integration strategies, we employed a case study design. This qualitative method appeared appropriate for gaining a thorough understanding of the system under investigation (Stake, 1988; Yin, 1994).

\subsection{Sample}

The research, conducted between 2003 and 2005, consisted of two phases. In the first phase a literature analysis was conducted to explore the existing body of knowledge on product innovation processes and customer integration practices. In parallel, the theoretical insights were validated in expert workshops and contracted research projects with industrial goods developers in Northern Europe in order to find inconsistencies and further research requirements which are most relevant. This literature analysis and practical reflection led to the two research questions which were introduced above.

The second phase attempted to specify the identified aspects in the context of the two research questions. To gain such farther-reaching insights, we carried out an in-depth analysis of selected projects and companies (Stake, 1988; Eisenhardt, 1989a; Yin, 1994). According to Eisenhardt (1989a) between four and ten cases usually work well; so we choose four companies in which the product innovation process could be studied most comprehensively. The criteria for selecting firms were based on their potential for learning and on depth rather than representativeness and breadth.

In this case, we chose four industrial goods developers: Hilti (Liechtenstein), Buechi Labortechnik (Switzerland), IDEO (Germany), and Tribecraft (Switzerland). All firms apply the whole spectrum from low- to high-tech. Hilti was chosen due to its reputation as a company that successfully practices a lead-user approach. Buechi excels in its closeness to customers (distributors) and users throughout its product innovation process. Furthermore, as a result of the authors' close collaborations with this company in previous research projects, we could ensure access to sensitive customer information and a broad data validation process. IDEO - broadly investigated in NPD literature - and Tribecraft engaged in very tight collaborations with their customers and have developed product innovations that stand out in terms of their degree of newness and superior design.

Whereas Hilti and Buechi are in-house developers, IDEO and Tribecraft represent professional technical service firms, in the following named development contractors, that develop product innovations with clients on a project basis. Therefore, IDEO and 
Tribecraft work according to a different industrial product development model than the in-house developers.

This development model has been included in the research to cover the approach of the most innovative new products they release and to ensure, therefore, that different customer integration strategies can be identified. In order to allow for a comparison within the different development models, the investigation takes place on the level of specific NPD projects and their practices.

\subsection{Data collection and analysis}

In the second phase of the research we collected data through personal, face-to-face interviews, 30-90 min in length, with chief technology officers, $R \& D$ directors, R\&D managers, developers, engineers, and product managers. We recorded a total of 39 hours of interviews (see interview list in Appendix). The selected participants represent different levels of customer contact and NPD responsibilities. Most interview partners had personally participated in customer integration activities, and their responses focused on specific projects from the preceding 18 months. We also interviewed some informants more than once. We used an interview guideline to maintain the coherence of the data collection and analysed the interviews according to the following aspects:

- product innovation processes

- customer integration activities at various stages in the process

- customers' contributions

- degrees of newness of the resulting products.

We augmented the interview data with desk research, namely, analyses of company publications (internal journals, annual reports, internet web pages), internal memos, and presentations. Site visits and workshop participation enabled complementary personal observations. Follow-up sessions with the interview partners ensured the reliability and validity of the analysis and confirmed the case study interpretations drawn from the interviews (Yin, 1994).

\section{Findings}

This section presents the exploratory findings from our case studies as they relate to the two research questions. They accrued throughout the process of analysing data through data coding and category grouping (Voss et al., 2002). These categories were for question one (type of customer contribution):

- roles of customers involved in NPD projects

- customers' offers (know-how and/or financial attractiveness).

For question two (timing of major customer participation) they were:

- stage of customer contact in the innovation process 
- intensity of customer integration (number and length of contacts)

- activities of visualising and transferring intermediary NPD results to customers.

As a further category, companies' technology and market position for the development project was included.

The subsequent creation of subcategories through grouping the categories' specifications led us to the characteristics shown subsequently (Sections 5.1 and 5.2) and finally to the result of two distinct customer integration strategies which will be presented in Section 6.

\subsection{Type of customer contribution}

Studying whether and how the type of customer contribution influences the degree of newness for product innovations, we found two prevalent types of customer contributions:

- major contributions in terms of determining new product scope and functionalities

- minor contributions associated with verifying product relevance and feedback about design and handling.

For example, whereas the in-house developer Hilti asked customers to ensure the relevance of a product idea for the market and tested development activities at customers' sites, Buechi, IDEO, and Tribecraft all sought customer contributions to determine the scope of a new product. We offer an overview of these two prevalent contribution types, as well as the customers' specific involvement in our cases, in Table 2.

Table 2 Overview of case study data: customer contributions to NPD

\begin{tabular}{|c|c|c|c|c|}
\hline $\begin{array}{l}\text { Type of } \\
\text { customer } \\
\text { contribution }\end{array}$ & Hilti & Buechi & $I D E O$ & Tribecraft \\
\hline $\begin{array}{l}\text { Determination } \\
\text { of product } \\
\text { scope and } \\
\text { functionality }\end{array}$ & $\begin{array}{l}\text { Customers } \\
\text { generally not } \\
\text { involved; mostly } \\
\text { predetermined } \\
\text { by Hilti }\end{array}$ & $\begin{array}{l}\text { Customers partially } \\
\text { involved; selection } \\
\text { of customers' } \\
\text { (sub-)processes that } \\
\text { can be facilitated } \\
\text { by Buechi products }\end{array}$ & $\begin{array}{l}\text { Customers } \\
\text { involved; } \\
\text { identification of } \\
\text { distinguishing } \\
\text { innovation } \\
\text { potentials from } \\
\text { the product's use } \\
\text { situation }\end{array}$ & $\begin{array}{l}\text { Customers } \\
\text { involved; } \\
\text { identification of } \\
\text { distinguishing } \\
\text { innovation } \\
\text { potentials from } \\
\text { the product's } \\
\text { use situation }\end{array}$ \\
\hline $\begin{array}{l}\text { Relevance } \\
\text { verification } \\
\text { and design } \\
\text { adjustments }\end{array}$ & $\begin{array}{l}\text { Customers involved; } \\
\text { input idea collection } \\
\text { to verify } \\
\text { applicability in the } \\
\text { new market, } \\
\text { provision of } \\
\text { abundant test } \\
\text { information }\end{array}$ & $\begin{array}{l}\text { Customers involved; } \\
\text { adjustment of the } \\
\text { product-customer } \\
\text { interface (product } \\
\text { design and handling) }\end{array}$ & $\begin{array}{l}\text { Customers } \\
\text { involved; } \\
\text { adjustment of the } \\
\text { product-customer } \\
\text { interface (product } \\
\text { design and } \\
\text { handling) }\end{array}$ & $\begin{array}{l}\text { Customers } \\
\text { involved; } \\
\text { adjustment of the } \\
\text { product-customer } \\
\text { interface (product } \\
\text { design and } \\
\text { handling) }\end{array}$ \\
\hline
\end{tabular}


The difference between Hilti on the one hand and Buechi, IDEO, and Tribecraft on the other hand can be explained with of Hilti's strong product leadership position and highly specialised expertise in the projects and product areas analysed. That is,

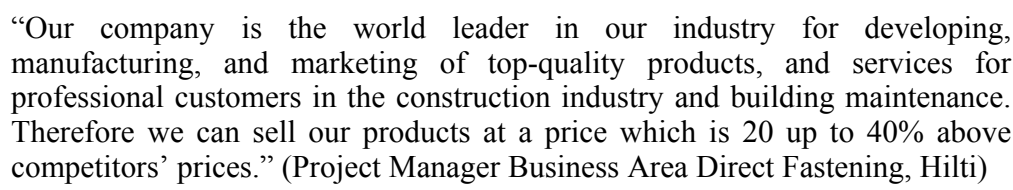

In other words, in the investigated projects Hilti brought its mature technology to the market with assistance from customers, which was used only for fine tuning. Overall, customers accepted what is technically feasible, which ensured product compatibility with their practices, needs, and values. The resulting product innovations' degree of newness remained rather low; totally new product solutions that induced any sort of revolution in the industry for these product ranges have not occurred in recent years.

The in-house developer Buechi and the development contractors revealed insights into innovation projects in product areas in which they did not hold a leadership position. For Buechi, this situation arose because it was attempting to enter a new product field, so it needed customers to identify new and best product application areas. For IDEO and Tribecraft, the scenario of not holding a leadership position was a consequence of their business activities, which were not dedicated to one industry exclusively. Because these development contractors had only limited in-house competencies for specific innovation projects, they had to connect with industry specialists, clients, and product users during their development activities. Buechi had significant in-house industry competence, but had to collaborate with different product dealers and product end users to collect the know-how and expertise necessary to enter into a new product range. Therefore, the products that IDEO, Tribecraft, and Buechi produced were less dominated by the perspective of a single development company and more open to combining divergent technological possibilities and market needs.

Furthermore, in the projects of IDEO and Tribecraft, the customer frames the product scope and functionality and therefore strongly influences the product specifications:

\begin{abstract}
"Already in the idea phase, we observe the relevant stakeholders in their environment, visualise what we find, and build rough prototypes, which we discuss with the client. These prototypes build the basis to realise the next project step." (Tribecraft founder and partner)
\end{abstract}

That is, IDEO and Tribecraft shaped the product together with their clients from the very beginning and considered users for inspiration and validation. The development contractors attempted to achieve clear product differentiations - that is product innovations with high degrees of newness - together with customers and detached from existing industry norms.

\title{
5.2 Timing of major customer participation
}

Studying the impact of the timing of customer integration suggests that in all cases, customer contributions differed in the different stages of NPD. This is similar to Biemans's (1992) and Gruner and Homburg's (2000) findings which state that the intensity of customer integration typically varies with the stage of the product innovation 
process. In Table 3, we list the customer contributions during the different stages of the investigated NPD projects, as well as the media employed to transfer these contributions between the customers' and the developers' sites over time. In addition, Table 3 provides a more concise overview of a simplified innovation process model that applies to all four cases and makes the data comparable. To do this, we reduced the innovation process applied to the projects investigated to three stages:

- idea generation

- concept development

- product design.

Table 3 Overview of case study data: customer contributions throughout the steps of the product innovation projects

\begin{tabular}{|c|c|c|c|c|}
\hline $\begin{array}{l}\text { Innovation } \\
\text { phase }\end{array}$ & Hilti & Buechi & $I D E O$ & Tribecraft \\
\hline $\begin{array}{l}\text { Idea } \\
\text { generation }\end{array}$ & $\begin{array}{l}\text { Customer } \\
\text { contributions: } \\
\text { Providing } \\
\text { trends, insights } \\
\text { about } \\
\text { willingness to } \\
\text { pay } \\
\text { Media: } \\
\text { Questionnaire }\end{array}$ & $\begin{array}{l}\text { Customer } \\
\text { contributions: } \\
\text { Providing } \\
\text { relevant product } \\
\text { functionalities } \\
\text { Media: } \text { Paper } \\
\text { concept, } \\
\text { questionnaire }\end{array}$ & $\begin{array}{l}\text { Customer } \\
\text { contributions: } \\
\text { Providing } \\
\text { product use } \\
\text { and technical } \\
\text { parameters } \\
\text { Media: } \\
\text { Questionnaire, } \\
\text { video, rough rapid } \\
\text { prototypes }\end{array}$ & $\begin{array}{l}\text { Customer contributions: } \\
\text { Providing long-term } \\
\text { product strategy and } \\
\text { character } \\
\text { Media: } \text { Questionnaire, } \\
\text { video, moodboard, rapid } \\
\text { prototypes }\end{array}$ \\
\hline $\begin{array}{l}\text { Concept } \\
\text { development }\end{array}$ & $\begin{array}{l}\text { Customer } \\
\text { contributions: } \\
\text { Providing } \\
\text { feedback from } \\
\text { functional } \\
\text { prototype test } \\
\text { in focus groups } \\
\text { Media: } \\
\text { Functional } \\
\text { prototype }\end{array}$ & $\begin{array}{l}\text { Customer } \\
\text { contributions: } \\
\text { Providing test } \\
\text { feedback } \\
\text { regarding } \\
\text { relevant } \\
\text { specifications } \\
\text { Media: } \\
\text { Functional model } \\
\text { (prototype) }\end{array}$ & $\begin{array}{l}\text { Customer } \\
\text { contributions: } \\
\text { Providing more } \\
\text { use and technical } \\
\text { information, } \\
\text { feedback to } \\
\text { mock-ups and rapid } \\
\text { prototypes, insights } \\
\text { into user 'personas' } \\
\text { Media: } \\
\text { Mock-ups, rapid } \\
\text { prototypes }\end{array}$ & $\begin{array}{l}\text { Customer contributions: } \\
\text { Providing more use and } \\
\text { technical information, } \\
\text { insights into use } \\
\text { workflows } \\
\text { Media: Mock-ups, rapid } \\
\text { prototypes }\end{array}$ \\
\hline $\begin{array}{l}\text { Product } \\
\text { design }\end{array}$ & $\begin{array}{l}\text { Customer } \\
\text { contributions: } \\
\text { Providing } \\
\text { design } \\
\text { adjustments } \\
\text { Media: Final } \\
\text { prototype }\end{array}$ & $\begin{array}{l}\text { Customer } \\
\text { contributions: } \\
\text { Providing } \\
\text { marginal design } \\
\text { adjustments } \\
\text { Media: Final } \\
\text { prototype }\end{array}$ & $\begin{array}{l}\text { Customer } \\
\text { contributions: } \\
\text { Providing feedback } \\
\text { on final (integrated) } \\
\text { design and functional } \\
\text { prototype } \\
\text { Media: Final } \\
\text { prototype }\end{array}$ & $\begin{array}{l}\text { Customer contributions: } \\
\text { Providing feedback on } \\
\text { final (integrated) design } \\
\text { and functional prototype } \\
\text { Media: } \\
\text { Final prototype }\end{array}$ \\
\hline
\end{tabular}

We do not address market introduction, because this step does not influence product development activity per se. 
According to our case studies customer participation varied strongly with the project stage and media employed. As we reveal in Table 3, the use of early physical prototypes throughout the product innovation process linked strongly to the extent to which customers determine the product. For example, because IDEO and Tribecraft confronted clients and users continuously with physical prototypes, they were able to collect many contributions, which they included into the next prototypes.

In contrast, Hilti and Buechi drove their investigated NPD projects with in-house knowledge and collected customer contributions only to adjust product design and handling (i.e., Hilti) or the scope of the specifications (i.e., Buechi). As members of these companies stated clearly,
“To assure the customers' product acceptance and willingness to buy the completely new product concept, we present functioning prototypes to selected customers in the concept stage: product users test the prototypes on the construction sites and provide feedback about the prototypes functionalities. With these tests, the product concept is clarified during site visits and interviews with potential customers." (Project Manager, Business Area Direct Fastening, Hilti)
"We bring a functional model, in which we try to implement the different market characteristics identified during the market analysis, to customers' sites in the alpha test. This functional model is focused on technical feasibility, containing the deciding product functionalities. The alpha test is conducted to get reliable and concluding feedback about the new product's market relevance as well as to check product functionalities. (Head Business Unit Research and Discovery, Buechi)

To explain further why the development contractors employ physical prototypes, we noted that they possessed much less industry expertise than Hilti and Buechi in their markets. Therefore, IDEO and Tribecraft had to absorb much more know-how from customers from the very beginning of their NPD projects. Their less specialised in-house industry know-how forced them to learn from the early physical representations of products under development.

In turn, IDEO's and Tribecraft's new products were not dominated by their own perspective but rather remained extremely open to different technological possibilities and market needs. The resulting products entailed a higher degree of newness and offered noticeable superiority to customers and the developer compared to industry standards. This high degree of newness appeared as a promise in the development contractors' business models and resulted in visible effects, such as design awards. If these companies could not develop products that featured noticeable improvements over industry standards, no in-house developers would hire them for product developments.

In contrast, Hilti and Buechi possessed abundant expertise and thus did not experience pressure to seek external development expertise; moreover, they involved customers less than development contractors did. In their investigated development projects, the in-house perspective dominated the new product - unless they outsourced technological and design developments by collaborating, e.g., with development contractors. 
Overall, Buechi and Hilti usually started from core competences related to their industry, whereas the development contractors remained independent of an existing product or competence portfolio. As a result, the development contractors acted independently of their industry competence, whereas the in-house developers usually engaged in company competence-dependent practices. Independence enabled the former to flexibly match among the technical skill bases of the developers, the technical and market skill bases of clients, and the product application skills of users. In-house developers, in contrast, usually maintained a stronger and more specialised focus on their industry, which increased the challenge of making connections between existing solutions and problems across industry boundaries. Therefore, the in-house developers' projects released customer information in a form that mirrors the industry average.

\section{Anticipation and brokering}

Chapter 5 showed that the projects' degree of newness differed with the type of customer contribution and the timing of customer participation. The investigated projects, in which the company did not occupy a technology or market leadership position, integrated customers mainly to define the new product's scope and features (cf. IDEO, Tribecraft, and Buechi partially) and considered them throughout the whole innovation process. These projects resulted in product innovations with a relatively high degree of newness. The investigated projects of the leading-edge company, in contrast, integrated customers for fine tuning and adjustment (cf. Hilti) mostly after concept development, because they already were in a technological head start position. This resulted in product innovations with a lower degree of newness. Section 5 further showed that a product innovation's degree of newness changes with the intensity of customer integration; the more input and know-how were integrated from customers and external specialists (e.g., because of the company's insufficient pre-existing in-house industry expertise), the greater was the potential for a high degree of newness in a new product solution.

Besides the explorative investigation of the two research questions we also found the impact of the company's position in terms of in-depth know-how about the project's market and its related technology. We refer to this position as industry establishedness. High industry establishedness implies that a company takes a market-leading position in the specific product field or has a technological head-start. Moreover the company judges the uncertainty associated with NPD requirements to remain low. Therefore, it generally considers customers and external specialists only for marginal product decisions as it already possesses leading development competencies. In contrast, lower industry establishedness implies that a company has a weak position in the targeted product market, must develop or acquire technological competencies, and considers the uncertainty surrounding NPD requirements high. For such projects, companies integrated customers and external specialists into fundamental product decisions, not just fine tuning. The relation between industry establishedness, the customer integration strategy and the resulting new product's degree of newness is shown in Figure 3.

In turn, we posit from the cases we investigated that high industry establishedness induces companies to integrate customers in a way that finally leads to a lower degree of product newness. This is, because the market and technology are well known, and the project rarely considers perspectives external to the industry. The effect is enhanced by the maturity of an industry: a more mature industry strengthens the tendency toward 
lower product newness, because product improvements become more and more marginal. Only the entrance of new competitors or introduction of disruptive technologies (Christensen, 1997; Paap and Katz, 2004), which are hardly foreseeable developments, provoke significant changes. However, lower industry establishedness tends to prompt a rather high degree of newness, because the development team strives for new perspectives about product development and often includes solutions and know-how from other industries.

Figure 3 Impact of companies' industry establishedness on customer integration strategies

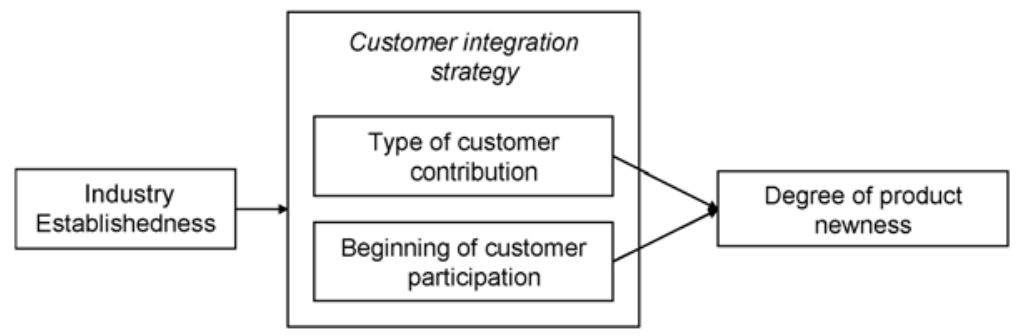

This finding and its impact on two identified customer integration strategies is shown in the following section. The strategies are

- $\quad$ anticipating customer needs

- technology and application brokering.

\subsection{Anticipating customer needs}

Companies in situations of a good market position and a technological advantage often can anticipate or foresee customer needs (Seely Brown and Hagel, 2005). As a customer integration strategy for an innovation project, anticipation relies on the company's effort to push product innovation resources and technological potential into areas in which they are likely to achieve improvements. Companies following an anticipation strategy even try to shape industry standards in certain product areas. Hilti, for example, provides new technological possibilities, which enable its customers to achieve new performance levels by applying the new products. However, this strategy faces severe challenges when unanticipated market shifts occur. According to Seely Brown and Hagel (2005), organisations that use push approaches run the danger of either piling up inventories or turning costly somersaults to keep up with unanticipated market shifts. Therefore, NPD teams should take care not to reinvent the wheel and come up with an 'innovation' that has already been developed and implemented elsewhere (Gassmann and von Zedtwitz, 2003). Furthermore, close, long-lasting relationships with leading customers help the company to not miss evolving customer trends.

Figure 4 exemplifies the anticipation strategy with the Hilti example: as a consequence to its high industry establishedness it integrates customers for relevance verification and design adjustment (type of customer integration) after concept development (timing of major customer participation). The degree of product newness of the investigated projects was considered rather low. 
Figure 4 Framework of anticipation strategy

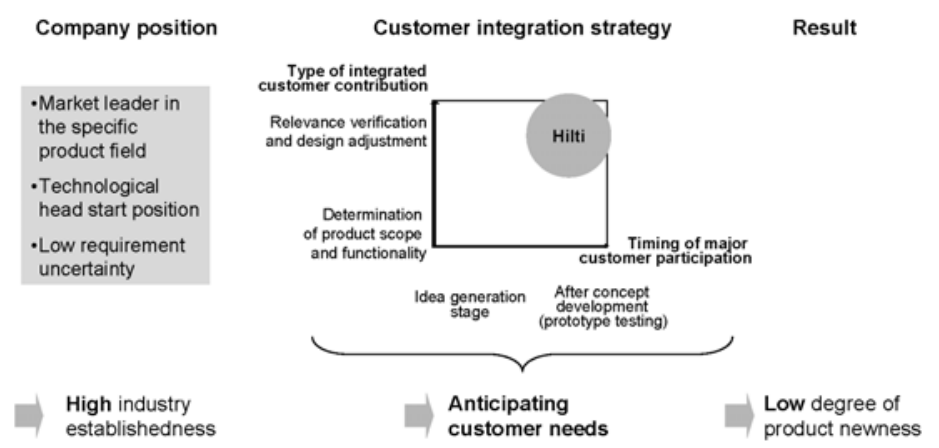

\subsection{Technology and application brokering}

The second customer integration strategy, technology and application brokering, promotes imitation across industries and linkages between technology and demand know-how from previously separate areas (Hargadon and Sutton, 1997; Servatius, 2004). The rationale underlying this approach centres on bringing together the relevant problem information with the actual problem-solving capabilities, even if development competence does not reside within the development team at the start of the project (von Hippel, 1994). This approach includes experimentation, improvisation, and rapid learning. Therefore, developers should participate in distributed resource networks in which customers play major roles and operate across traditional corporate boundaries, collaborate to achieve innovative solutions, and learn from one another to speed their capability building (Seely Brown and Hagel, 2005).

The two cases involving projects from the development contractors IDEO and Tribecraft illustrate the implementation of this approach as a customer integration strategy. Both companies apply open innovation (Chesbrough, 2003; Gassmann, 2006) by connecting with highly specialised engineers from the client company during a project:
"We see ourselves as intermediaries who connect specialists from all relevant sectors which are required to develop an extraordinary innovative new product." (Tribecraft founder and partner)
"We pick the things each client does well, and assimilate them into our methodology. We're not good at innovation because of our flawless intellects, but because we've done thousands of products, and we've been mindful." (Tom Kelley, IDEO founder, qtd. in Perry, 1995, p.17)

Due to the high skill levels of the development contractors' staff, the learning effect that results from their collaboration is very high. In turn, the distributed and continuously reformed development contractor teams can generate truly innovative ideas across different projects. Clients and customers take the perspective of third parties and provide insights about the different needs associated with the latest technological solutions. Therefore, the development team of the contractors represents an arbitrator between the potential of the technology and customer needs, acts as an interface, and plays important technology transfer and adoption roles (Veryzer and Borja de Mozota, 2005).

Figure 5 exemplifies the brokering strategy with the IDEO and the Tribecraft examples: as a consequence to their low industry establishedness they integrate 
customers for determination of product scope and functionality (type of customer integration) and already at the idea generation stage (timing of major customer participation). The degree of product newness of the investigated projects was high.

Figure 5 Framework of brokering strategy

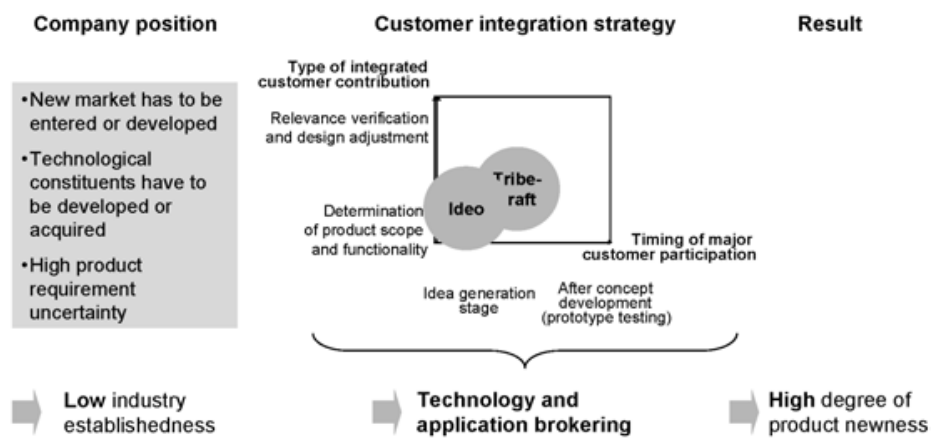

\subsection{Hybrid strategies}

Our case studies of differing product innovation contexts led to the two very different customer integration strategies, as they were presented above. These two strategies are expected to be only two among other possible strategies. They are assumed to be hybrids containing anticipation as well as brokering characteristics.

The Buechi case is an example of such a hybrid: while the development team integrated customers for defining the relevant new product functionalities at the idea stage, customers afterwards participated only for test feedback on the functional model and again for marginal design adjustments in the design phase (see Table 3). Therefore, Buechi sought for less interaction with its customers throughout the development process than IDEO and Tribecraft did, although it started with technology and application brokering activities similar to the contractors. As a result and taking Buechi's industry establishedness into account, it intensively integrated its customers at a very early stage in order to develop a product with a high degree of newness (brokering), but let them participate only punctually in the later stages, since its in-house development know-how and experience was sufficient for a matching concept development (anticipation). It is unclear at this point if the resulting product's degree of newness would have been increased if customer participation also during concept development would have been maintained at a higher level.

Moreover, other dimensions than the range between anticipation and brokering are expected to play a role when it comes to defining and categorising customer integration strategies. As an example, these dimensions could be financial attractiveness of the customer (Gruner and Homburg 2000), existing liabilities or legally defined exclusiveness agreed between developer and customer.

\section{Study limitations}

There are several limitations to our study. First, by choosing to focus on a very limited set of industrial NPD, the results by necessity do not consider NPD projects with other 
characteristics. The fact that only two in-house developers and two development contractors were investigated represents a major limitation, but helped to analyse opposed ends of the spectrum from the very beginning of this research project. The result can only be applied to other in-house developers and development contractors with similar innovation processes, and extensions to other industries than those of the cases studied must be made carefully. An area for future research is the replication of the study in other industry settings, whereas consumer goods pose a different problem than industrial goods.

Second, our analysis has been restricted to a Northern European context. Although in the design of the study no aspects were incorporated that are specific to Northern Europe, an international replication study could yield interesting results. Thus, a closer and differentiated analysis of geographies and specific industry structures could be a rewarding subject for additional investigations.

Generally, an empirical investigation of the research questions and development and testing of research hypotheses on a broader scale should better assess the identified customer integration strategies as well as their underlying customer contributions and customer participation. Also, research propositions and hypotheses on hybrid and further possible customer integration strategies should be examined: other dimensions, such as financial attractiveness of the customer (Gruner and Homburg, 2000), are expected to play a role for defining and categorising customer integration strategies.

The results of the study are finally summarised in the subsequent section.

\section{Summary and managerial implications}

Research in the field of NPD and innovation management suggests that effective product development requires an interplay between developers and customers (Eisenhardt and Tabrizi, 1995; von Hippel et al., 1999). The results from this study build on existing literature and extend the customer integration research to the terrain of specific customer integration strategies.

Therefore, we explored customer contributions and customer participation as characteristics in which customer integration strategies differ. Two research questions helped to explore the characteristics and offered a basis for investigating the core issues. Besides customer contributions and customer participation we found industry establishedness as a crucial aspect influencing the customer integration strategy.

Thus, our case studies of four different developing companies have brought out two largely differing customer integration strategies for innovation projects: anticipation and brokering: If a firm chooses to use anticipation - e.g., to advance an industry standard - a starting position with high industry establishedness is recommended. That is, the company should

- $\quad$ enjoy a market-leading position in the specific product area

- a technological head start

- little uncertainty about product innovation requirements.

In this scenario, NPD involves pushing resources into areas of anticipated innovation potential and foreseeing and even shaping customer needs. 
In contrast, to implement technology and application brokering successfully, the firm should rely on low industry establishedness in the specific project area. This strategy focuses on bringing together the different perspectives of various specialists to cross-fertilise findings from different industries. Its successful application depends on

- $\quad$ scarce consideration of previous knowledge about the targeted product market

- the need to develop or acquire technological competencies

- uncertainty about product innovation requirements.

The brokering strategy potentially leads to product innovations with a higher degree of newness.

Furthermore, the cases led to the identification of an example of a hybrid strategy, containing anticipation and brokering elements. Thus, the different strategies could serve as a guideline for decision making regarding the appropriate customer integration actions, taking into account the preferred degree of product newness and the company's position in terms of industry establishedness.

We also found in our cases that a product innovation portfolio requires implementing different customer integration strategies for different projects or business areas. Paap and Katz (2004) recommended that within a portfolio, different types of innovation projects should be balanced, because those with a high degree of newness usually involve more project risk. It is therefore assumed that, on the one hand, companies should engage in projects to improve current product segments that entail relatively low product requirement uncertainty, such as those that anticipate customer needs. These projects ensure the introduction of a competitive product into the market in a foreseeable timeframe and generally work best with a traditional product innovation process.

On the other hand, companies should include innovation projects that do not follow this established process, without the goal of entering the market at a precisely planned time, and thus offer the flexibility of responding to new opportunities discovered throughout the project itself during intense interactions with customers. These projects could apply technology and application brokering, because of the high level of product requirement uncertainty and the potential for a higher degree of product newness. To use technology and application brokering, the careful organisation of activities seems important in order to ensure that resources allocation occurs appropriately and retaining transparency among the departments involved. A possible solution might be using an 'in-house broker', who knows the location of the resources required to realise a good idea and possesses requisite contacts with valuable customers.

This research attempted to demonstrate that despite intense investigations into the area of customer integration into product innovation processes, gaps remain in the field of customer integration strategies. Our further research will concentrate on affirming our results and on identifying further existing customer integration strategies.

\section{References}

Atuahene-Gima, K. (1995) 'An exploratory analysis of the impact of market orientation on new product performance: a contingency approach', Journal of Product Innovation Management, Vol. 12, No. 4, pp.275-293.

Atuahene-Gima, K. (1996) 'Market orientation and innovation', Journal of Product Innovation Management, Vol. 13, No. 5, pp.456-457. 
Bacon, G., Beckman, S., Mowery, D. and Wilson, E. (1994) 'Managing product definition in high-technology industries: a pilot study', California Management Review, Vol. 36, No. 3, pp.32-56.

Biemans, W.G. (1992) Managing Innovation within Networks, Routledge, London.

Billington, J. (1998) 'Customer-driven innovation', Harvard Management Update, Vol. 3, No. 7, pp.1-3.

Brockhoff, K. (2003) 'Customers' perspectives of involvement in new product development', International Journal of Technology Management, Vol. 26, Nos. 5-6, pp.464-481.

Bruce, M., Leverick, F., Littler, D. and Wilson, D. (1995) 'Success factors for collaborative product development: a study of suppliers of information and communication technology', $R \& D$ Management, Vol. 25, No. 1, pp.33-44.

Buergel, H.D. and Zeller, A. (1997) 'Controlling kritischer Erfolgsfaktoren in der Forschung und Entwicklung', Controlling, Vol. 9, No. 4, pp.218-225.

Callahan, J. and Lasry, E. (2004) 'The importance of customer input in the development of very new products', R\&D Management, Vol. 34, No. 2, pp.107-120.

Chesbrough, H.W. (2003) Open Innovation: The New Imperative for Creating and Profiting from Technology, Harvard Business School Press, Boston.

Christensen, C.M. (1997) The Innovator's Dilemma, Harvard Business School Press, Boston.

Ciccantelli, S. and Magidson, J. (1993) 'From experience: consumer idealized design: involving consumers in the product development process', Journal of Product Innovation Management, Vol. 10, No. 4, pp.341-347.

Clark, K.B. and Fujimoto, T. (1990) 'The power of product integrity', Harvard Business Review, Vol. 68, No. 6, pp.107-118.

Dahan, E. and Hauser, J.R. (2002) 'The virtual customer', Journal of Product Innovation Management, Vol. 19, No. 5, pp.332-353.

De Propis, L. (2002) 'Types of innovation and inter-firm co-operation', Entrepreneurship and Regional Development, Vol. 14, No. 4, pp.337-353.

Doney, P.M. and Cannon, J.P. (1997) 'An examination of the nature of trust in buyer-seller relationships', Journal of Marketing, Vol. 61, No. 2, pp.35-51.

Eisenhardt, K.M. (1989a) 'Building theories from case study research', Academy of Management Review, Vol. 14, No. 4, pp.532-550.

Eisenhardt, K.M. (1989b) 'Making fast strategic decisions in high-velocity environments', Academy of Management Journal, Vol. 32, No. 3, pp.543-576.

Eisenhardt, K.M. and Tabrizi, B.N. (1995) 'Accelerating adaptive processes: product innovation in the global computer industry', Administrative Science Quarterly, Vol. 40, No. 1, pp.84-110.

Ganesan, S. (1994) 'Determinants of long-term orientation in buyer-seller relationships', Journal of Marketing, Vol. 58, No. 2, pp.1-19.

Gassmann, O. (2006) 'Opening up the innovation process: towards an agenda', R\&D Management, Vol. 36, No. 3, pp.223-228.

Gassmann, O. and von Zedtwitz, M. (2003) 'Trends and determinants of managing virtual R\&D teams', R\&D Management, Vol. 33, No. 3, pp.243.

Gebhardt, A. (1996) Rapid Prototyping - Werkzeuge für die schnelle Produktentwicklung, Hanser, München.

Griffin, A. and Hauser, J.R. (1993) 'The voice of the customer', Marketing Science, Vol. 12, No. 1, pp.1-27.

Griffin, A. and Hauser, J.R. (1996).' Integrating R\&D and marketing: a review and analysis of the literature', Journal of Product Innovation Management, Vol. 13, No. 3, pp.191-213.

Gruner, K.E. and Homburg, C. (2000) 'Does customer interaction enhance new product success?', Journal of Business Research, Vol. 49, No. 1, pp.1-14. 
Hamel, G. and Prahalad, C.K. (1994) Competing for the Future, Harvard Business School Press, Bosten.

Hargadon, A. (2005) 'Technology brokering and innovation: linking strategy, practice, and people', Strategy and Leadership, Vol. 33, No. 1, pp32-36.

Hargadon, A. and Sutton, R.I. (1997) 'Technology brokering and innovation in a product development firm', Administrative Science Quarterly, Vol. 42, No. 4, pp.716-749.

Hauschildt, J. and Schlaak, T.M. (2001) 'Zur messung des innovationsgrades neuartiger produkte', Zeitschrift für Betriebswirtschaft, Vol. 71, No. 2, pp.161-182.

Herstatt, C. and Verworn, B. (Eds.) (2002) Bedeutung und Charakteristika der frühen Phasen des Innovationsprozesses, Management der frühen Innovationsphasen - Grundlagen Methoden - Neue Ansätze, Gabler, Wiesbaden.

Herstatt, C. and von Hippel, E. (1992) 'From experience: developing new product concepts via the lead user method: a case study in a 'low-tech' field', Journal of Product Innovation Management, Vol. 9, No. 3, pp.213-221.

Holman, R., Kaas, H-W. and Keeling, D. (2003) 'The future of product development', The McKinsey Quarterly, Vol. 3, pp.2-8.

Jeppesen, L.B. and Molin, M.J. (2003) 'Consumers as co-developers: learning and innovation outside the firm', Technology Analysis and Strategic Management, Vol. 15, No. 3, pp.363-383.

Kim, J. and Wilemon, D. (2002) 'Focusing the fuzzy front-end in new product development', $R \& D$ Management, Vol. 32, No. 4, pp.269-279.

Kline, S.J. (1985) 'Innovation is not a linear process', Research Management, Vol. 28, pp.36-45.

Koen, P., Ajamian, G., Burkart, R., Clamen, A., Davidson, J., D’Amore, R., Elkins, C., Herald, K., Incorvia, M., Johnson, A., Karol, R., Seibert, R., Slavejkov, A. and Wagner, K. (2001) 'Providing clarity and a common language to the 'fuzzy front end', Research Technology Management, Vol. 44, No. 2, pp.46-55.

Kohli, A.K. and Jaworski, B.J. (1990) 'Market orientation: the construct, research propositions, and managerial implications', Journal of Marketing, Vol. 54, No. 2, pp.1-17.

Kohn, S. and Niethammer, R. (2002) 'Aufgabengerechte Kundeneinbindung im Innovationsprozess', Das innovative Unternehmen, Barske, Gerybadze, Hünninghausen and Sommerlatte: Düsseldorf, Symposion.

Lempres, E.C. (2003) 'A product is born', The McKinsey Quarterly, Vol. 3, p.1.

Lengnick-Hall, C.A. (1996) 'Customer contributions to quality: a different view of the customer-oriented firm', Academy of Management Review, Vol. 21, No. 3, pp.791-810.

Lilien, G.L., Morrison, P.D., Searls, K., Sonnack, M. and von Hippel, E. (2002) 'Performance assessment of the lead user idea-generation process for new product development', Management Science, Vol. 48, No. 8, pp.1042-1059.

Lüthje, C., Herstatt, C. and von Hippel, E. (2005) 'User-innovators and 'local' information: the case of mountain biking', Research Policy, Vol. 34, No. 6, pp.951-965.

Lynch, P. and O'Toole, T. (2003). 'After von Hippel: the state of user involvement research in new product development', 19th IMP-Conference, Lugano, Switzerland.

MacCormack, A., Verganti, R. and Iansiti, M. (2001) 'Developing products on 'internet time': the anatomy of a flexible development process', Management Science, Vol. 47, No. 1, pp.133-150.

Macdonald, S. (1995) 'Too close for comfort? The strategic implications of getting close to the customer', California Management Review, Vol. 38, No. 4, pp.8-27.

Martin, J. (1995) 'Ignore your customer', Fortune, May, pp.123-126.

McDermott, C.M. and O'Connor, G.C. (2002) 'Managing radical innovation: an overview of emergent strategy issues', Journal of Product Innovation Management, Vol. 19, No. 6, pp.424-438. 
Morrison, P.D., Roberts, J.H. and Midgley, D.F. (2004) 'The nature of lead users and measurement of leading edge status', Research Policy, Vol. 33, No. 2, pp.351-362.

Nambisan, S. (2002) 'Designing virtual customer environments for new product development: toward a theory', Academy of Management Review, Vol. 27, No. 3, pp.392-413.

O'Connor, G.C. (1998) 'Market learning and radical innovation: a cross case comparison of eight radical innovation projects', Journal of Product Innovation Management, Vol. 15, No. 2, pp.151-166.

Paap, J. and Katz, R. (2004) 'Anticipating disruptive innovation', Research Technology Management, Vol. 47, No. 5, pp.3-22.

Paustian, C. (2001) 'Better products through virtual customers', MIT Sloan Management Review, Vol. 42, No. 3, pp.1, 2.

Perry, T.S. (1995) 'How small firms innovate: designing a culture for creativity', Research Technology Management, Vol. 38, No. 2, pp.14-17.

Rice, M., Kelley, D., Peters, L. and O'Connor, G.C. (2001) 'Radical innovation: triggering initiation of opportunity recognition and evaluation', $R \& D$ Management, Vol. 31, No. 4, p.12.

Scott, W., Rivera, T. and Tate, A. (2003) 'Turn your customers into interns', Quality Progress, November, pp.31-37.

Seely Brown, J. and Hagel, J. (2005) 'From push to pull: the next frontier of innovation', The McKinsey Quarterly, Vol. 3, pp.1-6.

Servatius, H-G. (2004) 'Next practice des innovations managements', Information Management and Consulting, Vol. 19, Sonderausgabe, pp.1-8.

Shaw, B. (1985) 'The role of the interaction between the user and the manufacturer in medical equipment innovation', $R \& D$ Management, Vol. 15, No. 4, pp.283-292.

Song, X.M. and Montoya-Weiss, M.M. (1998) 'Critical development activities for really new versus incremental products', Journal of Product Innovation Management, Vol. 15, No. 2 , pp.124-135.

Stake, R.E. (1988) 'Case study methods in educational research: seeking sweet water', in Jaeger, R. (Ed.): Complementary Methods for Research in Education, American Educational Research Association, Washington DC, pp.253-300.

Urban, G.L. and von Hippel, E. (1988) 'Lead user analyses for the development of new industrial products', Management Science, Vol. 34, No. 5, pp.569-582.

Veryzer, R.W. and Borja de Mozota, B. (2005) 'The impact of user-oriented design on new product development: an examination of fundamental relationships', Journal of Product Innovation Management, Vol. 22, No. 2, pp.128-143.

von Hippel, E. (1976) 'The dominant role of users in the scientific instrument innovation process', Research Policy, Vol. 5, No. 3, pp.212-239.

von Hippel, E. (1977) 'Transferring process equipment innovations from user-innovators to equipment manufacturing firms', $R \& D$ Management, Vol. 8, No. 1, pp.13-22.

von Hippel, E. (1978) 'Successful industrial products from customer ideas', Journal of Marketing, Vol. 42, No. 1, pp.39-49.

von Hippel, E. (1986) 'Lead users: a source of novel product concepts', Management Science, Vol. 32, No. 7, pp.791-805.

von Hippel, E. (1988) The Sources of Innovation, Oxford University Press, New York.

von Hippel, E. (1994) 'Sticky information and the locus of problem solving: implications for innovation', Management Science, Vol. 40, No. 4, pp.429-439.

von Hippel, E., Thomke, S. and Sonnack, M. (1999) 'Creating breakthroughs at 3M', Harvard Business Review, Vol. 77, No. 5, pp.47-55.

Voss, C., Tsikriktsis, N. and Frohlich, M. (2002) 'Case research in operations management', International Journal of Operations and Production Management, Vol. 22, No. 2, pp.195-219. 
Wynstra, F. and Pierick, E. (2000) 'Managing supplier involvement in new product development: a portfolio approach', European Journal of Purchasing and Supply Management, Vol. 6, No. 1, pp.49-57.

Yin, R.K. (1994) Case Study Research: Design and Methods, Sage Publications, Thousand Oaks, CA

\section{Appendix}

\section{List of interviews}

Exploration of product innovation processes and customer integration practices on a broad scale (33 interviews)

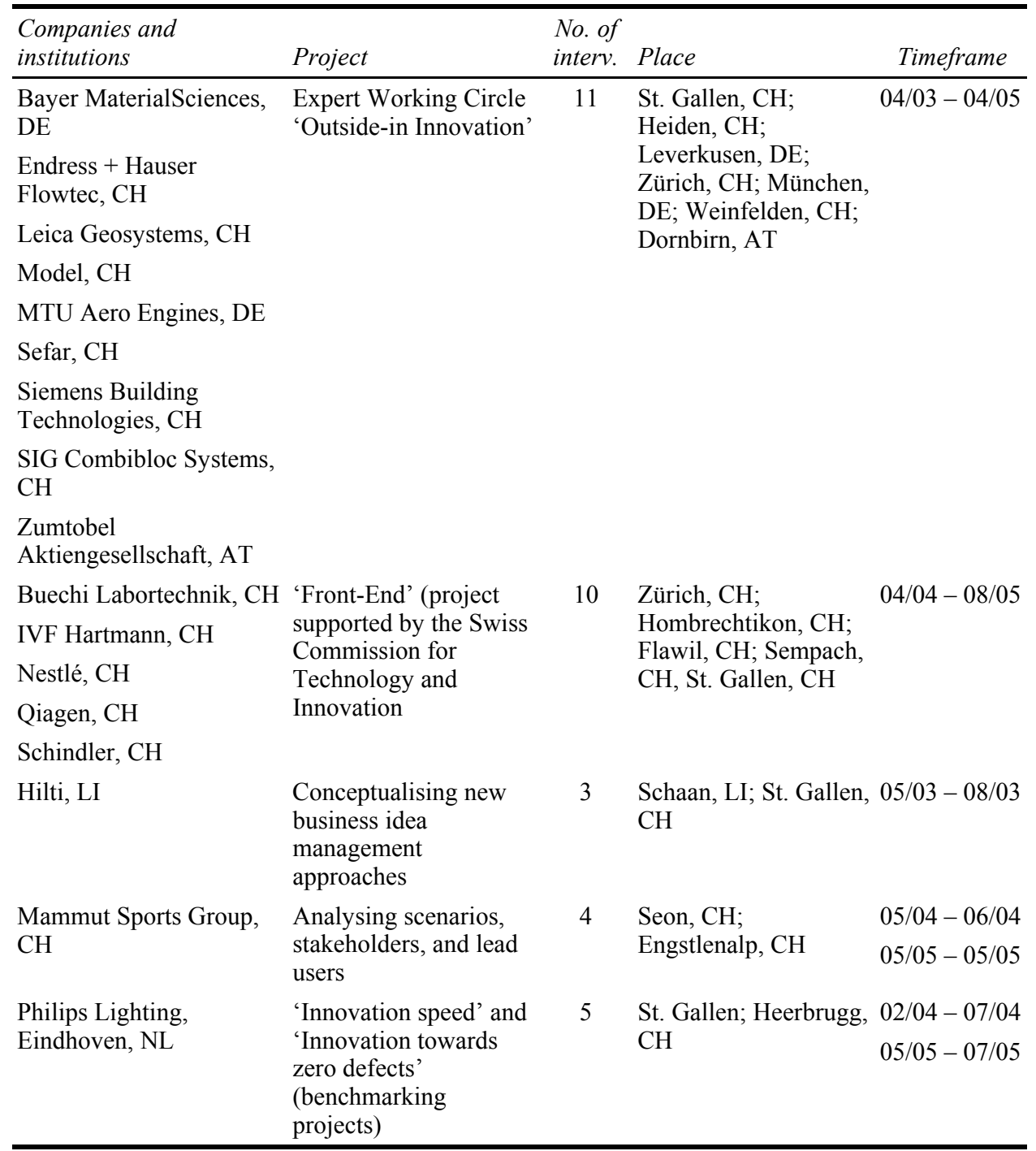




\section{Appendix (continued)}

\section{List of interviews}

In-depth case studies (33 interviews)

\begin{tabular}{|c|c|c|c|}
\hline Company & Position & Place & Date \\
\hline Hilti & Project Manager Business Area Direct Fastening & Schaan, LI & 03.06 .2005 \\
\hline Hilti & $\begin{array}{l}\text { Segment Manager Mechanical and Electrical, Business } \\
\text { Area Direct Fastening }\end{array}$ & Schaan, LI & 03.06 .2005 \\
\hline \multirow[t]{2}{*}{ Hilti } & $\begin{array}{l}\text { Corporate Innovation Manager, New Business and } \\
\text { Technology }\end{array}$ & Schaan, LI & 03.06 .2005 \\
\hline & Head of Corporate Technology & & \\
\hline Hilti & $\begin{array}{l}\text { Senior Vice President New Business and Technology, } \\
\text { Member of the Corporate Management Group (CMG) }\end{array}$ & Schaan, LI & 03.06.2005 \\
\hline Hilti & Project Manager Business Area Direct Fastening & Schaan, LI & 11.08.2005 \\
\hline Hilti & $\begin{array}{l}\text { Senior Vice President New Business and Technology, } \\
\text { Member of the Corporate Management Group (CMG) }\end{array}$ & Schaan, LI & 19.12.2005 \\
\hline Hilti & Project Manager Business Area Direct Fastening & Schaan, LI & 19.12.2005 \\
\hline Buechi & Marketing Manager, BU Research and Discovery & Zurich, $\mathrm{CH}$ & 20.04 .2004 \\
\hline Buechi & Head Construction, BU Research and Discovery & HombrechtikonCH & 03.06 .2004 \\
\hline Buechi & $\begin{array}{l}\text { Head Business Unit Research and Discovery } \\
\text { Head Construction, BU Research and Discovery }\end{array}$ & Flawil, $\mathrm{CH}$ & 18.11 .2004 \\
\hline Buechi & $\begin{array}{l}\text { Head Business Unit Research and Discovery } \\
\text { Head Construction, BU Research and Discovery } \\
\text { Marketing Manager, BU Research and Discovery }\end{array}$ & Flawil, $\mathrm{CH}$ & 02.12 .2004 \\
\hline Buechi & $\begin{array}{l}\text { Head Business Unit Research and Discovery } \\
\text { Product Manager } \\
\text { Product Manager } \\
\text { Project responsible } \\
\text { Head Laboratory } \\
\text { Consultant (former lead user) now providing external NPD } \\
\text { support }\end{array}$ & Flawil, $\mathrm{CH}$ & 16.01.2005 \\
\hline Buechi & Head Business Unit Research and Discovery & Flawil, $\mathrm{CH}$ & 07.04 .2005 \\
\hline Buechi & Head Business Unit Research and Discovery & Falwil, $\mathrm{CH}$ & 22.4 .2005 \\
\hline Buechi & Head Business Unit Research and Discovery & Flawil, $\mathrm{CH}$ & 09.05 .2005 \\
\hline Buechi & Head Business Unit Research and Discovery & St. Gallen, $\mathrm{CH}$ & 18.05 .2005 \\
\hline Buechi & Head Business Unit Research and Discovery & St. Gallen, CH & 25.08 .2005 \\
\hline IDEO & Head IDEO Germany & St. Gallen, $\mathrm{CH}$ & 14.02.2005 \\
\hline IDEO & Head IDEO Germany & St. Gallen, $\mathrm{CH}$ & 02.06 .2005 \\
\hline IDEO & Head IDEO Germany & Munich, DE & 27.07.2005 \\
\hline IDEO* & Business Developer & St. Gallen, $\mathrm{CH}$ & 24.08 .2005 \\
\hline Tribecraft & Partner and product developer & Flawil, $\mathrm{CH}$ & 02.12 .2004 \\
\hline Tribecraft & Partner and product developer & Zurich, $\mathrm{CH}$ & 03.08 .2005 \\
\hline Tribecraft* & Partner and product developer & Zurich, $\mathrm{CH}$ & 30.08 .2005 \\
\hline
\end{tabular}

*Telephone interview. 